\title{
Critical Analysis of the Applicability of the ISO 9001 Standard in Higher Education Institutions
}

\author{
Raphael. M. Jingura, Reckson Kamusoko \\ and Julius Tapera
}

\begin{abstract}
This article analyses the applicability of the ISO 900I standard in Higher Education Institutions. Initially developed for application in industry, this standard sets the requirements for implementing a quality management system in an organisation. Over the years, it has been adapted to the Higher Education sector as a quality management standard. The standard is analysed in terms of the relevance of its philosophy to Higher Education; its suitability for this sector; the ease of implementation; its effect on quality assurance and enhancement; and its impact on quality. The mechanisms by which it affects quality management are also presented. The analysis shows that ISO 900I is based on a philosophy that resonates with general approaches to quality assurance in Higher Education Institutions and that its seven principles provide a sound basis for effective quality management. It can be adapted to the peculiarities of this sector and, although it imposes a considerable workload, it can be applied with ease. There is thus both a theoretical and empirical basis for the ISO 9oor standard to promote quality assurance and enhancement in Higher Education. Academic provision and administrative services can benefit from its adoption and it can promote and strengthen the development of a quality culture, especially
\end{abstract}

ABOUT THE AUTHORS: RAPHAEL. M. JINGURA Senior researcher and founding director of the Directorate of Quality Assurance at Chinhoyi University of Technology, Zimbabwe. E-mail: rjingura@gmail.com.

RECKSON KAMUSOKO Researcher and founding member of the Directorate of Quality Assurance at Chinhoyi University of Technology, Zimbabwe. E-mail: rkamsoko. kamusoko@gmail.com.

JULIUS TAPERA Senior institutional analyst and founding acting director of Quality Assurance Directorate at Lupane State University, Zimbabwe. E-mail: jtapera@lsu.ac.zw. 
when staff are deeply engaged in the process. It is thus concluded that the ISO 900I standard provides a framework for quality management that is applicable to the Higher Education sector.

Key words: ISO 900I, quality assurance, quality management, quality management system, higher education institutions

Cet article analyse l'applicabilité de la norme ISO 9oor dans les Institutions d'Enseignement Supérieur. Initialement développée pour l'industrie, cette norme établit les pré-requis pour mettre en place un système de gestion de la qualité dans une organisation. Au fil des années, il a été adapté au secteur de l'Enseignement Supérieur comme norme de gestion de la qualité. Cette norme est analysée sous plusieurs angles: la pertinence de sa philosophie pour l'Enseignement Supérieur, son aptitude au secteur, la facilité de sa mise en oeuvre, son effet sur le contrôle et l'amélioration de la qualité, et son impact sur la qualité. Les mécanismes avec lesquels la norme produit un effet sur la gestion de la qualité sont aussi présentés. L'analyse montre que ISO 900I est fondé sur une philosophie non loin des approches globales de contrôle de qualité dans les Institutions d'Enseignement Supérieur et que ces sept principes fournissent une base solide pour une gestion de la qualité efficace. Il peut être adapté aux particularités du secteur et, bien qu'il impose une charge de travail considérable, il peut être mis en place facilement. Il y a ainsi une base à la fois théorique et empirique pour que la norme ISO 90oI optimise le contrôle et l'amélioration de la qualité dans l'Enseignement Supérieur. La prestation universitaire et les services administratifs peuvent bénéficier de son adoption et elle peut promouvoir et renforcer le développement d'une culture de qualité, en particulier quant le personnel est activement impliqué dans le processus.

\section{Introduction}

Against the backdrop of an increasingly knowledge-driven society, quality management is gaining momentum in the Higher Education (HE) sector (Pavel, 20I2). Several factors, including the need for accountability and the relevance of $\mathrm{HE}$ to society have contributed to the emergence of the quality movement in this sector (Manatos et al., 20I7). This has led to emergence of quality management systems (QMS) in higher education institutions (HEIs), most of which are imported from industry (Rosa et al., 20I2). Quality assurance (QA) has become a global HE phenomenon, with the primary focus of enhancing educational outcomes (Ewell, 20Iо; Kliot and Bykovskaya, 20II; Yuan, 20Iо).

While most of the QA models used in HE have been adapted from industry (Niedermeier, 20I7), this has not been without its challenges. Some studies argue that these models are not suitable for HE (Srikanthan and Dalrymple, 2003); however, Becket and Brookes' (2008) review of pertinent case studies found the opposite to be true. More nuanced views have highlighted that some aspects of these models are scale-neutral and can be applied to HE. The main challenge has been both definitional and operational. From a definitional perspective, terms like customer, scientific method, waste and product do not fit well with HE (Rosa et al., 20I2). Srikanthan and Dalrymple (2003) highlight the differences between industrial and educational processes, with the latter being more complex and variable than the former. Furthermore, HE has multiple stakeholders with different expectations of its role and perceptions of quality.

The quality management (QM) models used in HE include Total Quality Management (TQM), the ISO 9000 series, the European Foundation for Quality Management Excellence Model (EFQM), Balanced Scorecard (BSC), Malcolm Baldridge award, and SERVQUAL, amongst others (Becket and Brookes, 2008; Niedermeier, 20I7). These have solid traction in industry. Total Quality Management is the most common approach at the international level (Niedermeier 20I7), while ISO 900I, EFQM and the BSC are also popular in HE (Rosa et al., 20I2). Efforts have also been made to develop QA models tailored for HE, with many based on ISO 9000, TQM and Malcolm Baldridge (Neidermeier, 20I7). The focus has been on the particularities of the core academic processes of teaching and learning (Becket and Brookes, 2008) as it has been argued that these cannot be equated to industrial processes. Examples include the Standards and Guidelines for Quality Assurance in the European Higher Education Area (ESG) (ENQA et al., 20I5; Srikanthan and Dalrymple, 20I4), the ISO-based TQM model (Borahan and Ziarati, 2002) and the excellence model (Pires da Rosa et al., 200I, 2003). Srikanthan and Dalrymple's (20I4) model is an exception as it is based on educational theories and the ESG is part of the Bologna process in Europe.

The ISO 900I standard is one of the most well-known QM models in HE (Rosa et al., 20I2) and is a popular choice among educational institutions (Thonhauser and Passmore, 2006) despite the fact that some studies have pointed to gaps specific to the field of HE. The standard sets the requirements for implementing a quality management system (QMS) in an organisation. The International Organisation for Standardisation (ISO) (2005) defines a QMS as a system that directs and controls an organisation with respect to quality. The ISO 900I standard is generic and can be applied by any organisation, irrespective of the products and services it provides, its size or the nature of its operations (ISO, 2005).

Driven by the quality movement and the fact that quality has become a mark of distinction in international HE markets (Blackmore, 2009), in 
modern times, many HEIs are seeking ISO certification (Stojanovic, 20I5; Chiarini, 20I5). The aim is to enhance operational efficiency, build teamwork among departments, and ensure customer satisfaction (Zabadi, 2013; Hussein et al., 20I7). According to Mola (20I7), some institutions are motivated by the prestige associated with ISO 900I certification. Isomorphic pressure (Papadimitriou and Westerheijden, 20Iо) and external pressure from government (Papadimitriou, 20II) have also led to the adoption of this standard. During the I990s, when the ISO standard first assumed prominence in the HE sector, several reasons were cited for its adoption, including claims that it renders operations more efficient and improves the quality of services and academic provision (Van den Berghe, I998; Kasperavičiūté, 20I3). Llach et al. (20II) reported that the education sector was ranked $12^{\text {th }}$ out of 39 ISO 900 I certified sectors. Furthermore, between 2004 and 2008 , the number of certificates issued to the education sector increased by more than 40\% (Kasperavičiūtè, 20I2). However, it is difficult to establish how many of these pertain to HEIs (Kasperavičiūte, 20I3). Empirical and theoretical studies on the use of the ISO 900I standard in HE include Thonhauser and Passmore (2006); El Abbadi et al. (2014); Martin and Thawabieh (20I8); Chiarini (20I5); Moturi and Mbithi (20I5); Papadimitriou and Westerheijden (20I0); Heras-Saizarbitoria and Boiral (20I5); and Kasperavičiūtė-Černiauskienè and Serafinas (20I8). The results are mixed and it has been difficult to prove causality when it comes to the standard's impact on teaching and learning. Furthermore, its precise effect on QM in HE has not been adequately explained and there has been inadequate focus on the centrality of the standard's philosophy with regard to QM in HE. Finally, theoretical and empirical evaluation is required that takes into account recent experiences in HE. This article focuses on the theoretical aspects of the standard as derived from its provisions and presents an analytical framework that can be used to determine its applicability in HE. Its findings will be useful to QA researchers and practitioners.

\section{Quality Management in Higher Education}

Quality management is a holistic management philosophy that focuses on the maintenance and continuous improvement of all the functions within an organisation, with the goal of meeting or exceeding customer and other stakeholder requirements (Kaynak, 2003). In HEIs, it includes quality control, quality assurance, and quality assessment and enhancement (Vlăsceanu et al., 2007; Niedermeier, 20I7). While QM is a broader concept than QA (Niedermeier, 20I7), these terms are at times used interchangeably, making it difficult to identify a consistent definition (Vlăsceanuet et al., 2007). As stated earlier, the ISO (2005) defines a QMS as a system that directs and controls an organisation with respect to quality.
In an era influenced by the performative and accountability logics of new public management, it is worth noting that at both the state and institutional levels, QA has become a form of governance (Rowlands, 20I2). Some scholars have referred to $\mathrm{QA}$ as a governance innovation in HE (King, 2007). In the changing relationship between the state and the university, QA is the primary tool used to govern HEIs (Morley, 2003; Filippakou and Tapper, 2008), where it exists as an ecosystem of external (EQA) and internal (IQA). The former refers to supra-institutional policies and practices to assure the quality of HEIs and programmes (Dill, 2007). Its agencies include private and public organisations which operate as government surrogates. National, regional and global EQAs regulate HE in various ways. For example, the ESG for the European Higher Education Area (ENQA et al., 20I5) sets standards and guidelines for both EQA and IQA in Europe. An African example is the framework of qualification standards in HE adopted by the Council on Higher Education in South Africa (CHE, 2OI3). It is important to note that IQA works within the provisions of EQA.

The International Network of Quality Assurance Agencies in Higher Education (INQAAHE) defines IQA as "the process, supported by policies and systems, used by an institution to maintain and enhance the quality of education experienced by its students and of the research undertaken by its staff" (INQAAHE, 20I8). It encompasses the QM mechanisms, instruments and systems within an HEI to ensure that the institution and its programmes are meeting their own standards and objectives (Sanyal and Martin, 2007). The essence of IQA is QM, and a QMS provides the processes, tools and instruments for that purpose. As stated earlier, QMSs in HE have been influenced by QM models in industry.

\section{Background to the ISO 9001 Standard in Higher Education}

The ISO published the ISO 900I, ISO 9002, and ISO 9003 standards in I987 that defined the requirements for a QMS (El Abbadi et al., 20I4). They were revised in I994, 2000, 2008 and 20I5. In 2000 , ISO 900I, ISO 9002 and ISO 9003 were merged to form ISO 900I. The ISO 9000 series has three standards. ISO 9000 covers Fundamentals and Vocabulary and sets out the basic concepts and terms used in the series of the standard. Its latest version is ISO 9000: 20I5. ISO 900I comprises Quality Management Systems - Requirements and its latest version is ISO 900I:20I5. Certification is only granted for this standard. ISO 9004 is titled: Managing for the sustained success of an organisation - A quality management approach. The latest version is ISO 9004: 2009 .

Higher education institutions, mainly in Europe and later in the US, began to implement the ISO 9000 series of standards around the mid- 
I990s (Van den Berghe, I997). Early adopters encountered numerous challenges (El Abbadi et al., 20I4) that mainly arose from the fact that the standard was developed for the manufacturing industry. The HE sector's peculiarities make it different from manufacturing and other service sectors (Kasperavičiūtè, 20I3). As such, the ISO 900I standard requirements needed to be interpreted in the education field (Karapetrovic et al., I998; Karapetrovic, 200I).

With time, the ISO became aware of these challenges and sought to ameliorate them. It published the first version of the International Workshop Agreement (IWA) 2 in 2003, which was coded IWA 2:2003 - Quality Management System - Guidelines for the Application of ISO 9001:2000 in Education (ISO, 2003). It was revised in 2007 (ISO, 2007). The guidelines in IWA 2 did not change the requirements of ISO 900I:2000, but sought to assist educational organisations to implement ISO 900I (ISO, 2007), with a focus on adapting its clauses to education (Caraman et al., 2008; Roszak, 2009). In this regard, IWA 2 defined four key terms, namely, customer, product, education provider, and educational organisation. The terms 'customer' and 'product' are controversial in HE and need to be tailored to resonate with this sector.

Several criticisms were levelled against the IWA 2 guidelines. One was that they neglected research activities (Rodman and Godnov, 20I0) because a product was defined as an educational outcome (El Abbadi et al., 20I4), which, taken literally, refers to teaching and learning. Another challenge was that IWA 2 defined a customer as a learner. In HE, a learner is both a customer (receives education) and an actor (contributes to learning) (Becket and Brookes, 2008). Furthermore, the guidelines did not place much emphasis on ethics and corporate social responsibility which are important in HE (El Abbadi et al., 2OI4).

After the publication of ISO 900I:2008, the IWA 2 working group developed ISO 9001:2008 Handbook for Educational Organisations - What to Do: Advice from IWA 2 Working Group (ISO, 2009). The handbook is more detailed than the IWA 2 guidelines and provides supplementary explanations and practical recommendations for the implementation of ISO 900I:2008 in education. It also widens the definition of product to the outputs of all activities undertaken by educational organisations, and includes aspects of financial resources. Both IWA 2 and the ISO 900I:2008 handbook provided guidance and were not intended for certification.

It is thus evident that there have been sustained efforts to enhance the applicability of the ISO 9oor standard to the education sector. A distinctive peculiarity of $\mathrm{HE}$ is the process of teaching and learning where contemporary pedagogies emphasise collaborative and interactive practices (Branch et al., 20I7). Another example is the shift from the dyadic model of student supervision to the co-construction of knowledge in group collaborations (Hyatt, 20I3). This changes the master-apprentice relationship between teacher and learner. These fundamental concepts should inform application of the standard in HE.

\section{Methods}

The study was a qualitative one that was mainly based on content analysis and interpretation. Interpretative analysis was used to situate the ISO 900I standard within the HE context. The analytical framework employed to provide philosophical explanations and identify key assessment parameters is presented in the following section. The theoretical analysis was based on the requirements of the standard, both in terms of its seven principles and its clauses. It involved interpreting the standard on the basis of its philosophy and clauses using experiences in HE reported in extant literature.

In order to provide a systematic framework for the analysis, the study was organised into the three stages of review suggested by Tranfield et al. (2003) and used by Tari and Dick (20I2).

The first stage was planning the analysis. The ISO 9oor standard was divided into two parts: I) its foundational aspects (seven principles), and 2) the requirements of its clauses (clauses 4 to Io). This formed the analytical framework for the analysis of: (I) consonance of the foundational aspects of the standard with QM in HE, and (2) applicability of the requirements of the clauses to HE.

The analysis was conducted in the second stage, when each of the standard's seven principles was interpreted. The clauses of the standard were analysed for their applicability to the HE sector using the parameters in the analytical framework.

In the third stage, reporting and dissemination, a descriptive and analytical narrative is provided for each parameter in the analytical framework. Figure I outlines the schematic representation of the analytical framework. The findings and discussion are based on the parameters in this framework and where possible, tables with qualitative data are presented.

\section{Analytical Framework}

The theoretical underpinning of the analytical framework is based on the general tenets of QM. Tari and Dick (2OI2) state that QM can be viewed as: I) a philosophy; and 2) a set of practices for the management of an organisation that goes beyond control of quality. Two observations can be made from this interpretation. First, a QM model must have principles that underpin it, and secondly, it must have requirements for its implementation. 
The analytical framework is based on the philosophy of the standard (P), and the standard's relevance to $\mathrm{HE}(\mathrm{R})$, implementation requirements (I) and outcomes (O). The acronym for the framework is thus PRIO. The reasons for selecting these parameters are set out in Table I below, while the framework is presented in Figure I. The first part of PRIO is made up of the seven principles of the ISO 900I standard, namely, customer focus; leadership; engagement of people; process approach; improvement; evidence-based decision making; and relationship management (ISO, 2OI5a). According to the ISO, following these principles will ensure that an organisation or business is able to consistently create value for its customers (ISO, 2OI5a). The core of the standard is the plan-do-check-act cycle (PDCA).

Table 1. Parameters of the Analytical Framework

\begin{tabular}{|l|l|}
\hline Parameter & Importance \\
\hline Philosophy & $\begin{array}{l}\text { Sets the principles underpinning the standard } \\
\text { This enables understanding of the logic that underpins the standard } \\
\text { Allows assessment for its application to HE }\end{array}$ \\
\hline Relevance & $\begin{array}{l}\text { Measures fitness of purpose of the standard to HE } \\
\text { Assesses whether the standard addresses the quality dimensions in HE }\end{array}$ \\
\hline Implementation & $\begin{array}{l}\text { Measures the relative ease of implementation of the standard } \\
\text { Determines the workload imposed on HE staff }\end{array}$ \\
\hline Outcomes & $\begin{array}{l}\text { Show the outcomes of application of the standard in HE } \\
\text { Quality assurance is increasingly becoming outcome-based }\end{array}$ \\
\hline
\end{tabular}

The second part of PRIO provides the focus areas for the analysis. Using an adaptation of the framework employed by Rodman and Godnov (2010), the focus is on the following:

I) Suitability

2) Ease of implementation

3) Effect on:

(a) Quality assurance

(b) Quality enhancement

(c) Quality culture
Figure 1. Analytical Framework

\begin{tabular}{|c|c|c|c|}
\hline Philosophy & \multicolumn{3}{|c|}{ Scope of the principles } \\
\hline Relevance & \multicolumn{3}{|c|}{ Suitability of the standard to $\mathrm{HE}$} \\
\hline Implementation & \multicolumn{3}{|c|}{ Ease of implementation in $\mathrm{HE}$} \\
\hline \multirow[t]{4}{*}{ Outcomes } & \multicolumn{3}{|c|}{ Effect on } \\
\hline & $\nabla$ & $\nabla$ & $\nabla$ \\
\hline & Quality & Quality & Quality \\
\hline & assurance & enhancenemt & culture \\
\hline
\end{tabular}

\section{Results and Discussion}

Philosophy of the Standard

The philosophy of the ISO 900 standard represented by its seven principles (Table 2) resonate with the major tenets of QM in HE, namely, accountability and improvement (Middlehurst and Woodhouse, I995). According to a study by UNESCO (20I8), 94\% of HEIs rated improvement of academic activities as a 'very important' component of IQA. This is confirmed by Tavares et al. (20I7) and Ewell (2002) who note that QA systems are expected to 'add value' to academic activities. The standard's seven principles easily apply to HE and can enhance IQA in HEIs. Indeed, it can be argued that they offer a generic philosophy that is applicable to QM in any sector. The issues of stakeholder satisfaction (Argyris, I999; Razavi et al., 20I2; Pateman, 20I2), leadership (Bond, 2000), and staff engagement (Pateman, 20I2; Tetteh, 20I8) focus on educational processes and evidence-based decision making that are central to IQA in HE (Niedermeier, 20I7; Blackmore, 2009). As such, the ISO 900I standard presents a QM philosophy that is immutable in HE. It is also worth noting that the PDCA cycle is both the implementation model for the ISO 90oI standard and the foundation of QM in HE (Niedermeier, 20I7), where it is commonly known as the quality cycle (plan-act-evaluate-improve).

Interpretation (Table 2) of the seven principles for the HE context shows that, from a philosophical perspective, the ISO 900I standard resonates with the logic behind IQA in HE. This sector has multiple stakeholders who must be satisfied with educational services and outcomes. Thus, a focus on 'customers' will lead to customer satisfaction. Student, graduate and employer satisfaction are important quality indicators in IQA (UNESCO, 20I8). Furthermore, EQAs use these indicators as a measure of the quality of teaching and learning (Spronken-Smith et al., 20I3). Another good example in Table I is the aspect of 'people engagement'. 
Internal quality assurance needs to be implemented with a deep sense of engagement by all staff. Staff support depends on several factors, including their sense of ownership which is influenced by their participation in the implementation of IQA (Cardoso et al., 20I8). The remainder of the principles are explained below (Table 2). All resonate with IQA as it exists in HE today. The interpretation of the principles in the table is based on the recommendations of several scholars on adaptation of the ISO standard to HE (Karapetrovic et al., I998; Karapetrovic, 200I; Roszak, 2009; Rodman and Godnov, 20I0; El Abbadi et al., 20I4).

\section{Suitability of the Standard}

The ISO 900I standard sets generic requirements for implementing a QMS regardless of the size and activities of an organisation (Rodman and Godnov, 20Io; El Abbadi et al., 20I4). By implication, this would mean that it can be applied in HE. The fact that academic processes cannot be equated to industrial processes has been a major argument against the standard. However, it has gained traction in HE over time and there is a growing body of literature on its use in this sector, evident in the exponential increase in journal articles from the mid-I99os (Van den Burghe, I997). Kasperavičiūtè-Černiauskienè and Serafinas (2018) note that a corpus of studies now exists on the ISO standard in HE. One of the first papers was written by Moreland and Clark (1998) and it highlighted the pros and cons of the standard. Karapetrovic et al. (I998), Karapetrovic (200I), Thonhauser and Passmore (2006), Chiarini (20I5) and several other scholars have demonstrated how a QMS based on ISO 90oI needs to be adapted in HE. Examples include Karapetrovic et al. (1998), Caraman et al. (2008), Karapetrovic (200I), Roszak (2009), Rodman and Godnov (20I0), and El Abbadi et al. (20I4).

It has generally been observed that QM models from industry do not recognise the centrality of student learning in HE (Becket and Brooks, 2008) and newer versions of the ISO standard have attempted to resolve this issue. Srikanthan and Dalrymple (2003) noted that the quality systems used in industry are process oriented and focus on the needs of the customer (Srikanthan and Dalrymple, 2003). However, teaching and learning cannot be regarded as a relationship between a business provider and 'customer' (Neidermeier, 20I7). The ISO 900I standard can be interpreted in a more nuanced way to address these concerns (Caraman et al., 2008; Roszak, 2009). As stated earlier, definitional issues have been contextualised to HE. A good example is the work of Karapetrovic (200I). It should also be noted that the standard has been found to work well with the service function of HE (Neidermeier, 20I7).
Table 2. Interpretation of the Seven Principles of the ISO gool Standard for IQA

\begin{tabular}{|c|c|c|}
\hline Principle & ISO interpretation (ISO, 2015a) & HE interpretation \\
\hline $\begin{array}{l}\text { Customer } \\
\text { focus }\end{array}$ & $\begin{array}{l}\text { Meeting and exceeding customer } \\
\text { needs } \\
\text { Attract and retain the confidence of } \\
\text { customers } \\
\text { Adapt to customers' future needs }\end{array}$ & $\begin{array}{l}\text { Understand the needs and expectations } \\
\text { of stakeholders } \\
\text { Focus on meeting the needs of users of } \\
\text { educational services and outputs } \\
\text { Adapt to changing needs for education } \\
\text { delivery and credentialing in a digitally } \\
\text { disrupted sector to remain relevant }\end{array}$ \\
\hline Leadership & $\begin{array}{l}\text { A unified direction or mission that } \\
\text { comes from strong leadership } \\
\text { Ensure that everyone in the } \\
\text { organisation understands the } \\
\text { organisational goals }\end{array}$ & $\begin{array}{l}\text { Academic and administrative leadership } \\
\text { set the tone for IQA } \\
\text { Ensure everyone understands the } \\
\text { purpose and benefits of IQA }\end{array}$ \\
\hline $\begin{array}{l}\text { Engagement } \\
\text { of people }\end{array}$ & $\begin{array}{l}\text { Create value through competent, } \\
\text { empowered and engaged people at } \\
\text { all levels of the organisation }\end{array}$ & $\begin{array}{l}\text { Recruit suitably qualified staff for all } \\
\text { portfolios } \\
\text { Decentralise IQA } \\
\text { Engage all levels of staff in IQA } \\
\text { development and implementation }\end{array}$ \\
\hline $\begin{array}{l}\text { Process } \\
\text { approach }\end{array}$ & $\begin{array}{l}\text { Understand activities as processes } \\
\text { that function as a system } \\
\text { Ensure everyone is familiar with the } \\
\text { organisation's activities and how } \\
\text { they fit together }\end{array}$ & $\begin{array}{l}\text { Understand teaching, learning, } \\
\text { research, and administration as } \\
\text { processes that form an ecosystem } \\
\text { Ensure academic and administrative } \\
\text { processes are clearly defined and } \\
\text { understood by everyone }\end{array}$ \\
\hline Improvement & $\begin{array}{l}\text { Successful organisations focus on } \\
\text { continuous improvement } \\
\text { Reacting to changes in the internal } \\
\text { and external environment is } \\
\text { necessary to continue to deliver } \\
\text { value to customers }\end{array}$ & $\begin{array}{l}\text { Focus on quality enhancement } \\
\text { Monitor and react to changes in the } \\
\text { environment } \\
\text { Consider IQA as a change driver }\end{array}$ \\
\hline $\begin{array}{l}\text { Evidence- } \\
\text { based decision } \\
\text { making }\end{array}$ & $\begin{array}{l}\text { Decisions based on analysis and } \\
\text { evaluation of data are more likely to } \\
\text { produce the desired results }\end{array}$ & $\begin{array}{l}\text { Measure institutional performance } \\
\text { using appropriate indicators } \\
\text { Decisions should be supported by the } \\
\text { results of evaluation }\end{array}$ \\
\hline $\begin{array}{l}\text { Relationship } \\
\text { management }\end{array}$ & $\begin{array}{l}\text { Identify important relationships with } \\
\text { interested parties such as suppliers } \\
\text { Set out a plan to manage the } \\
\text { relationships as this will drive } \\
\text { sustained success }\end{array}$ & $\begin{array}{l}\text { Identify relationships with internal and } \\
\text { external stakeholders } \\
\text { Manage relationships and drive } \\
\text { IQA through strong stakeholder } \\
\text { relationships }\end{array}$ \\
\hline
\end{tabular}


Furthermore, the gap between industry and the academic world is narrowing as a result of the increasing market orientation of HE (Rodman and Godnov, 20I0). Marketisation, commodification and privatisation have become common trends and the $\mathrm{HE}$ arena has become very competitive and dynamic. Adoption of the ISO 900I standard can positively impact leadership, operational efficiency, the organisation and the involvement of people, thereby enhancing institutional competitiveness (Bevans-Gonzales et al., 2004).

The latest version, ISO 900I:20I5, is less prescriptive and more flexible (Sickinger-Nagorni and Schwanke, 20I6). This is positive for HEIs that have tended to resist prescriptive approaches to QA. Extant literature shows evidence of resistance to QA in both its IQA and EQA forms (Stensaker, 2008; Blackmore, 2009; Brown, 20I3; Lucas, 20I4; Lust et al., 20I8), especially when it is seen to be externally driven (Lucas, 20I4). The one-size-fits-all approach is not appropriate for QA in HE (Ewell,2002). Flexibility, mainly in terms of inputs and processes, allows for innovation in $\mathrm{QM}$, but with no compromise on the quality of outcomes. Two of the novelties in this revised standard are that process management is gaining importance and riskbased thinking has been introduced. According to Kasperavičiūtė (2013), the main reasons for implementing the ISO 9ooI standard in HEIs is the need to improve internal processes and procedures, as well as institutional management, performance and effectiveness. This process approach (both academic and administrative) is central to IQA. The ISO 900I standard can help to describe process flows (academic and administrative), making implementation easier and enhancing understanding of how they interact.

\section{Ease of Implementation}

Challenges in implementing ISO 900I mainly relate to internal institutional issues (Kasperavičiūtè, 20I3). The main factors that determine ease of implementation include people, resources, education and communication (Ab Wahid and Corner, 2009). Implementation requires the involvement and commitment of all staff (Moturi and Mbithi, 20I5). Cardoso et al. (20I8) note that this might be difficult to achieve, while Singh and Sareen (2006) and Kasperavičiūte (2013) found that lack of staff motivation was a major hindrance to implementation of the standard. Karapetrovic (200I) observed that the main obstacle is staff's perception that it will restrict their academic freedom and that they will be blamed for identified quality problems. To this can be added the fear of increased bureaucracy and documentation (Karapetrovic, I998). Studies on the benefits and challenges of implementing the standard have been conducted in Lithuania (Kasperavičiūtè-Černiauskienè and Serafinas, 20I8), Lebanon (Hussein, Abou-Nassif et al., 20I7), Italy (Chiarini, 20I5), Kenya (Moturi and Mbithi,
20I5), Oman (Matin and Thawabieh, 20I8) and Malaysia (Muslim and Suradi, 20I2), amongst others.

Furthermore, staff in HEIs can perceive IQA as an additional form of bureaucracy (Rosa et al., 20I6). Indeed, it is often regarded as a form of managerialism (Lange and Kriel, 20I7), resulting in IQA not being accepted as an integral component of institutional development. The ISO standard also increases staff's workload as audits and documentation are required (Moturi and Mbithi, 20I5). All these challenges raise the need for internalisation of IQA by staff to the point where QA becomes an integral component of workflows. Allur et al. (20I4) concluded that a higher level of internalisation yields greater benefits from the adoption of ISO 900I. The standard's principles, particularly leadership, engagement of people and relationship management, can enhance such internalisation.

Implementing the ISO 900I standard requires time and other resources and should be regarded as an investment. Moturi and Mbithi (20I5) and Basir (2OI2) note that a lack of resources is one of the factors that limit implementation. Furthermore, staff need to invest their time in IQA-related activities and this should not be perceived as 'add-on work'.

Effective education and communication are required for implementation of the ISO 900I standard. People cannot implement what they do not understand. The need for continuous education and training of staff to enhance their performance is well recognised in HE (King, 2004). The ISO 9O0I implementation processes include staff training. Communication with internal and external stakeholders is also a critical success factor. Logical, rational and persuasive communication is particularly useful in industrial relations and organisational change (Choudhary and Rathore, 2013). Higher Education Institutions have complex structures and systems which can hinder effective communication. It is therefore important to ensure well-established communication mechanisms.

Effect on Quality Assurance and Enhancement

The need to continuously improve the quality of academic provision cannot be overemphasised. The ISO 900I standard will find traction in HE if it is seen to enhance QM. Moturi and Mbithi's (20I5) case study provides empirical evidence of the potential impact of ISO 900I on QA in HE, including improved customer satisfaction (staff, students), facilities, ranking, and staff competencies, and better compliance with EQA requirements.

An analysis of the standard's clauses is useful in explaining its outcomes in terms of quality assurance and enhancement. Clauses 4 to ro set out the standard's requirements and the mechanisms to assure and enhance quality (Table 3 ) are based on these. 
Table 3. Impact Mechanisms of the ISO goo Standard on Quality Assurance and Enhancement

\begin{tabular}{|c|c|}
\hline Clause & Impact mechanisms \\
\hline $\begin{array}{l}\text { 1. Context of the } \\
\text { organisation }\end{array}$ & $\begin{array}{l}\text { Helps the institution to determine internal and external issues } \\
\text { The institution understands the needs and expectations of its } \\
\text { internal and external stakeholders } \\
\text { It is easier to formulate a QMS to meet stakeholder needs and } \\
\text { expectations } \\
\text { Leads to more stakeholder satisfaction (fit-for-purpose services } \\
\text { and products) }\end{array}$ \\
\hline 2. Leadership & $\begin{array}{l}\text { Increases leadership commitment to implementation of QMS } \\
\text { Provides the quality policy which sets the quality objectives } \\
\text { Quality objectives make clear what the QMS must achieve } \\
\text { Roles, responsibilities and accountabilities are clear }\end{array}$ \\
\hline 3. Planning & $\begin{array}{l}\text { Enables actions to implement the QMS } \\
\text { Leads to constructive alignment of quality objectives with actions } \\
\text { Facilitates allocation of resources }\end{array}$ \\
\hline 4. Support & $\begin{array}{l}\text { Ensures allocation of resources to the QMS } \\
\text { Facilitates development of staff competencies for implementation } \\
\text { of the QMS } \\
\text { Competent staff are more likely to produce the desired results } \\
\text { Enhances internal and external communication } \\
\text { Builds documented information for evaluation }\end{array}$ \\
\hline 5. Operation & $\begin{array}{l}\text { Helps to define requirements for products and services and helps } \\
\text { the institution to ascertain its capacity to deliver them } \\
\text { Sets parameters for processes and products, enabling staff to be } \\
\text { properly guided } \\
\text { External services and products will meet the requirements } \\
\text { Measures are put in place to manage deviations from plans }\end{array}$ \\
\hline 6. Performance evaluation & $\begin{array}{l}\text { Ensures there are mechanisms for performance evaluation } \\
\text { Performance is evaluated, leading to awareness of performance } \\
\text { levels } \\
\text { Provides a clear basis for improvement }\end{array}$ \\
\hline 7. Improvements & $\begin{array}{l}\text { Helps to identify cases for improvement } \\
\text { Necessitates formulation of improvement plans } \\
\text { Leads to continuous improvement }\end{array}$ \\
\hline
\end{tabular}

Source: Information adapted from the ISO (2015a)
Table 3 explains the mechanisms by means of which the ISO 900I standard can positively impact quality assurance and enhancement. In other words, the QMS will be designed and implemented to achieve the institution's quality objectives.

Higher education is fraught with risks and risk management has become an important concern (Times Higher Education, 20I5). The concept of risk-based thinking is much more elaborate in the ISO 900I:20I5 version. Such thinking helps to determine the factors that can cause institutional processes and the QMS to deviate from planned results (ISO, 20I5b). Risks are inherent in many academic processes. For example, staff and student incivilities (Kelly, 20I7), resource shortages (Ndirangu and Udoto, 20II; Schneider, 2004; Abend et al., 2006) and other challenges are widely reported in this sector. The risk management tool set out in Clause 6 of the ISO 900I standard enables the resilience of a QMS (ISO, 20I5b).

\section{Effect on Quality Culture}

A quality culture (QC) is about developing organisational value systems that result in an environment conducive to the establishment and continual improvement of quality (Njiro, 20I6). Srinivasan and Kurey (20I4) define a $\mathrm{QC}$ in $\mathrm{HE}$ as, "an environment where staff and students not only follow quality guidelines but consistently see others talking about quality focused actions, hear others talking about quality and feel quality all around them." A QC is part of organisational culture and Rapp (2OII) states that it is an effective and meaningful way to develop QA mechanisms that ensure improved quality at all levels and support change in universities.

ISO 9004 requires quality management in HEIs to create a QC among employees that fosters continuous improvement in all key performance areas (Sickinger-Nagorni and Schwanke, 20I6). Although not specifically mentioned, this should be taken into account when implementing the ISO 900I:20I5 standard. Since implementation of the standard involves all staff, this can help to create a $\mathrm{QC}$ within an institution.

Moturi and Mbithi (20I5) found that implementation of the ISO 900I standard inculcated a QC among both staff and students at the University of Nairobi. Muslim and Suradi (2012) concluded that the implementation of the standard has a positive impact on the work culture and day-to-day task management and a negative impact on emotion. Other studies found that implementation of the standard promoted continuous improvement and a focus on customer satisfaction, enhancing service quality and operational efficiency (Psomas et al., 2013), and streamlining institutional processes (Okibo and Kimani, 20I3). Staff engagement, ownership, and relationship management, as espoused by the ISO 900I standard, can 
promote a QC that facilitates implementation of IQA and enhances the likelihood of a positive impact.

\section{Conclusion}

It can be concluded that the philosophy of the ISO 90oIstandard resonates with the tenets of QM in HE and that its requirements provide a QMS that is applicable to HEIs. Thus, the standard can be implemented as a QM model in HEIs and they can embrace its principles to develop and implement their QMS. This article has also argued that HEIs should move beyond the desire for ISO certification to develop a sustained QC. The analysis of the applicability of the standard in terms of suitability, ease of implementation, impact on quality assurance and enhancement, and fostering a QC revealed that the ISO 900I standard can embolden IQA. Furthermore, its various mechanisms can influence QM in HE. It is thus concluded that the ISO 9ooI standard is applicable to HE and can lead to improved educational services and outcomes.

\section{Recommendations}

It is recommended that further empirical studies be conducted on the applicability of the ISO 9ooI standard in HE across different HEIs, with a focus on its impact in this sector. Ewell (2002) introduced the concept of 'added value' with reference to QA. The essence is that QA must lead to improved institutional performance. Nielsen and Parker's (2OI2) model is an appropriate one to measure the impact of the ISO 9ooI standard. It covers broad aspects of HEIs beyond academic parameters and has been applied to IQA in this sector (Salto, 20I7). Future research could use Nielsen and Parker's (20I2) model to determine whether the standard enhances HEIs':

a) Social impact - This mainly refers to institutional reputation and serving the interests of society. Institutional reputation has become a significant market factor in HE in recent times.

b) Normative impact - This concerns the extent to which an HEI is committed to QMS for its own sake or due to moral commitment to assure and improve its performance. In other words, the target should not simply be certification but development of a sustainable QC.

c) Educational impact - This covers the standards and quality of educational programmes, teaching and learning, student performance and graduate employability.

d) Cultural impact - that refers to the extent to which the standard has fostered a QC in HE. Quality is not limited to measurement and evaluation procedures, but should also be viewed as part of organisational culture.

\section{References}

Abend, A., Ornstein, S.W., Baltas, E., de la Garza, J., Watson, C., Lange, K., and von Ahlefeld, H. (2006). Evaluating quality in educational facilities, PEB exchange programme on educational building, 2006/1. Paris: OECD Publishing.

Ab Wahid, R., and Corner, J. (2009). Critical success factors and problems in ISO 9000 maintenance. International Journal of Quality \& Reliability Management 26 (9), 88I-893.

Allur, E., Heras-Saizarbitoria, I., and Casadesús, M. (20I4). Internalisation of ISO 900I: A longitudinal survey. Industrial Management and Data Systems 114(6), 872-885.

Argyris, C. (I999). On organisational learning ( $2^{\text {nd }}$ edition). Cambridge, MA: Blackwell.

Basir, S. A. (20I2). Complying quality management system ISO 9000 requirements within higher education institutions (HEIs) in Muslim countries. World Journal of Islamic History and Civilisation 2(I), 30-43.

Becket, N., and Brookes, M. (2008). Quality management practice in higher education - What quality are we actually enhancing? Journal of Hospitality, Leisure, Sport and Tourism Education 7(I), 40-54.

Bevans-Gonzales, T., and Nair, A. (2004). The strengths and weaknesses of ISO 9000 in vocational education. Journal of Vocational Education and Training 56(2), 163-80.

Blackmore, J. (2009). Academic pedagogies, quality logics and performative universities: Evaluating teaching and what students want. Studies in Higher Education 34(8), 857-872.

Bond, S.L. (2000). Module 2: Academic Leadership. Gender Programme Training Modules 1-3: Management for development of women in higher education (Vol. I.3). UK: Association of Commonwealth Universities.

Borahan, N.G., and Ziarati, R. (2002). Developing quality criteria for applications in the higher education sector in Turkey. Total Quality Management 13(7), 913-926.

Branch, J., Hayes, S., Hørsted, A., and Nygaard, C. (eds) (20I7). Innovative teaching and learning in Higher Education (The Learning in Higher Education Series). Faringdon, UK: Libri.

Brown, S. (20I3). Change management in higher education: An empirical approach. ICICTE Proceedings, 89-97.

Caraman, I., Lazar, G., Bucuroiu, R., Lungu, O., and Stamate, M. (2008). How IWA 2 helps to implement a quality management system in Bacau University. International Journal for Quality Research 2(4), 305308.

Cardoso, S., Rosa, M.J., and Videira, P. (2018). Academics' participation in quality assurance: Does it reflect ownership? Quality in Higher Educa- 
tion 24(I), 66-8I.

Chiarini, A. (20I5). Effects of ISO 9001 Certification on Academic Processes. A first exploratory research from Italy. Paper presented at thei $8^{\text {th }}$ ToulonVerona International Conference on Excellence in Services, August 3I-September I, University of Palermo, Italy. Available at:http://www. toulonveronaconf.eu/papers/index.php/tvc/article/download/I83/I8I

Choudhary, M.K., and Rathore, N.S. (20I3). Role of effective communication in total quality management. International Journal of Scientific a Engineering Research 4(7), 2083-2090.

Coral, C., and Bokelmann, W. (20I7). The role of analytical frameworks for systemic research design, explained in the analysis of drivers and dynamics of historic land-use changes. Systems5(I), 20.doi:I0.3390/ systems5010020

Council on Higher Education (CHE). (20I3). A framework for qualification standards in higher education. Pretoria (South Africa): CHE.

Dill, D. D. (2007). Quality Assurance in Higher Education: Practices and Issues. In McGaw, B., Baker, E. and Peterson, P.P. (eds) International Encyclopedia of Education (3rd.ed.). Elsevier, 377-383.

El Abbadi, L., Bouayad, A., and Lamrini M. (20I4). ISO 900I and the field of higher education: Proposal for an update of the IWA 2 guidelines. Quality Approaches in Higher Education 4(2), I4-I9.

ENQA, ESU, EUA, EURASHE, Education International, BUSINESSEUROPE., \& EQAR. (20I5). Standards and guidelines for quality assurance in the European higher education area (ESG). Brussels, Belgium. https://enqa.eu/wp-content/uploads/20I5/II/ESG_20I5.pdf

Ewell, P.T. (2002). Delicate balance: The role of evaluation in management. Quality in Higher Education 8(2), I59-I7I.

Ewell, P.T. (20I0). Twenty years of quality assurance in higher education: What's happened and what's different? Quality in Higher Education 16(2), I74-176.

Filippakou, O., and Tapper, T. (2008). Quality assurance and quality enhancement in higher education: Contested territories? Higher Education Quarterly62(I/2), 84-Ioo.

Harvey, L. (2004-I4). Analytic quality glossary. Quality Research International. Available at: http://www.qualityresearchinternational.com/ glossary/

Heras-Saizarbitoria, I., and Boiral, O. (20I5). Symbolic adoption of ISO 9000 in small and medium sized enterprises: The role of internal contingencies. International Small Business Journal 33(3), $299-320$.

Hussein, B., Abou-Nassif, S., Aridi., M, Chamas, M., and Khachfe, H. (20I7). Challenges of implementation of ISO 900I:20I5 in the Lebanese higher education institutions. Journal of Resources Development and Management 33, 4I-5I.

Hyatt, D. (2013). The critical policy discourse analysis frame: helping doctoral students engage with the educational policy analysis. Teaching in Higher Education 18(8), 833-845.

International Network of Quality Assurance Agencies in Higher Education (INQAAHE). (20I8). Quality glossary. Available at: http://www.qualityresearchinternational.com/glossary/. Accessed I7 July 2018.

International Organisation for Standardisation (ISO). (2003). IWA 2: 2007: Quality management systems - Guidelines for the application of ISO 9001:2000 in education. Switzerland. Available at: https://www.iso.org/ standard/45805.html

International Organisation for Standardisation (ISO). (2005). ISO gooo: 2005: Quality management systems - Fundamentals and vocabulary. Geneva: International Organisation for Standardisation. Available at: https://www.iso.org/standard/42180.html

International Organisation for Standardisation (ISO). (2007). IWA 2: 2007: Quality management systems - Guidelines for the application of ISO 9001:2000 in education ( $2^{\text {nd }}$ edition). Switzerland. Available at: https:// www.iso.org/standard/45805.html

International Organisation for Standardisation (ISO). (2008). ISO 9001: 2008: Quality Management Systems -Requirements. Geneva: ISO. Available at: https://www.iso.org/standard/46486.html

International Organisation for Standardisation (ISO). (2009). ISO 9001: 2008: Handbook for Educational Organisations — What to do: Advice from IWA 2 working group. Switzerland.

International Organisation for Standardisation (ISO). (2015a). How to use it. Available at: http://iso_900I_20I5_how_to_use_it.pdf

International Organisation for Standardisation (ISO). (2OI5b). Risk-based thinking in ISO 9001:2015. Geneva: ISO. Available at: https://committee. iso.org/.../ISO\%20900I\%202015\%20.../ISO900I_20I5_and_Risk

Karapetrovic, S. (200I). ISO 9000 Quality System Development for Engineering Schools: Why and how should we do it? Paper presented at the International Conference on Engineering Education. August 6 - Io, Oslo, Norway. Available at: http://citeseerx.ist.psu.edu/viewdoc/down load?doi=Io.I.I.5.I89o\&rep=repi \&type=pdf

Karapetrovic, S., Rajamani, D., and Willborn, W. (I998). ISO 9oo q quality system: An interpretation for the university. International Journal of Engineering Education 14(2), I05-II8.

Kasperavičiūtè, R. (20I2). Approach of higher education institutions to ISO 900I standard: Reasons, issues and benefits of implementation. Public Policy and administration 11(4), 672-689.

Kasperavičiūtè, R. (20I3). Application of ISO 900I and EFQM excellence 
model within higher education institutions: practical experiences analysis. Social Transformations in Contemporary Society 1, 8I-92.

Kasperavičiūtė-Černiauskienè, R., and Serafinas, D. (20I8). The adoption of ISO 900 standard within higher education institutions in Lithuania: Innovation diffusion approach. Total Quality Management \& Business Excellence 29(I-2), 74-93.

Kaynak, H. (2003). The relationship between total quality management practices and their effects on firm performance. Journal of Operations Management 21(4), 405-435.

Kelly, K.R. (20I7). Identifying and coping with academic incivility, Part I: The Academic Department. The Department Chair 28(I), 20-22.

King, R. (2007). Governance and accountability in the higher education regulatory state. Higher Education 53, 4II-430.

King, H. (2004). Continuing professional development in higher education: What do academics do? Planet 13(I), 26-29.

Kliot, Y.M., and Bykovskaya, E.V. (20II). Quality management system as the main tool of international integration of educational organisations. Issues of Modern Science and Practice 2(33), 258-262.

Lange, L., and Kriel, L. (20I7). Integrating internal quality assurance at a time of transformation University of the Free State, South Africa. Paris: International Institute for Educational Planning. Available at: http:// unesdoc.unesco.org/images/0024/002495/249506E.pdf

Llach, J., Marimon, F., and Bernardo, M. (20II). ISO 900I diffusion analysis according to activity sectors. Industrial Management \& Data Systems $111(2), 298-316$

Lust, M., Huber, C., and Junne, J. (20I8). Academic identity as a discursive resource for resistance: The case of quality management in German higher education institutions. Higher Education Policy1-21, https://doi. org/I0.I057/s4I307-0I8-0116-6

Lucas, L. (20I4). Academic resistance to quality assurance processes in higher education in the UK. Policy and Society 33(3), 2I5-224.

Manatos, M.J., Sarrico, C.S., and Rosa, M.J. (20I7). The integration of quality management in higher education institutions: a systematic literature review. Total Quality Management \& Business Excellence 28(I-2), I59-I75.

Martin, A., and Thawabieh F. A. (2018). The effect of ISO 9oor to Oman education operational performance: Buraimi University College as a case study. International Journal of Applied Engineering Research 13(6), 3939-3947.

Middlehurst, R., and Woodhouse, D. (I995). Coherent systems for external quality assurance. Quality in Higher Education 1(3), 257-288.

Mola, N. B. (2007). The use of ISO 9001 Quality Standard in higher education institution libraries. Available at: http://bid.ub.edu/ıgbalag3.htm

Moreland, N., and Clark, M. (I998). Quality and ISO 9000 in educational organizations. Total Quality Management 9(2-3), 3II-320.

Morley, L. (2003). Quality and Power in Higher Education. Maidenhead: Society for Research into Higher Education and Open University Press.

Moturi, C., and Mbithi, P.M.F. (20I5). ISO 900I: 2008 implementation and impact on the University of Nairobi: A case study. The TQM Journal $27(6), 752-760$.

Muslim, N., and Suradi, M.Y.N.R. (20I2). The National University of Malaysia staff's perceptions of ISO 900I: 2008: A study on the effectiveness and the impacts on emotion. Journal of Applied Sciences Research 8(2), I035-1040.

Ndirangu, M., and Udoto, M.O. (20II). Quality of learning facilities and learning environment: Challenges for teaching and learning in Kenya's public universities. Quality Assurance in Education 19(3), 208-223.

Niedermeier, F. (20I7). Designing Effective Quality Management Systems in Higher Education Institutions. Module I. In S. Randhahn, and Niedermeier, F. (eds) Training on Internal Quality Assurance Series. Duisburg/Essen: DuEPublico.

Nielsen, V.L., and Parker, C. (2012). Mixed motives: Economic, social, and normative motivations in business compliance. Law and Policy 34, 428-462.

Njiro, E. (2016). Understanding quality culture in assuring learning at higher education institutions. Journal of Educational Policy and Entrepreneurial Research 3(2), 79-92.

Okibo, B.W., and Kimani, A.W. (2013). Effectiveness of ISO 900I: 2008 certification on service delivery of public universities in Kenya. European Journal of Business and Management 5(13), 232-242.

Organisation of Economic Cooperation for Development (OECD). (20I8). Glossary of statistical terms. Available at: https://stats.oecd.org/glossary/detail.asp? ID =6IO2

Papadimitriou, A. (20II). Reforms, leadership and quality management in Greek higher education. Tertiary Education and Management 17(4), 355372.

Papadimitriou, A., and Westerheijden, D. F. (2010). Adoption of ISO-oriented quality management system in Greek universities. Reactions to isomorphic pressures. The TQM Journal 22(3), 229-24I.

Pateman, C. (20I2). APSA presidential address: Participatory democracy revisited. Perspectives on Politics 10(I), 7-I9.

Pavel, A.P. (20I2). The importance of quality in higher education in an increasingly knowledge-driven society. International Journal of Aca- 
demic Research in Accounting, Finance and Management Sciences 2(I), I2O-I27.

Pires Da Rosa, M.J., Saraiva, P.M., and Diz, H. (200I). The development of an Excellence Model for Portuguese higher education institutions. Total Quality Management 12(7\&8), IоIо-IOI7.

Pires Da Rosa, M.J., Saraiva, P.M., and Diz, H. (2003). Excellence in Portuguese higher education institutions. Total Quality Management Q Business Excellence 14(2), I89-197.

Psomas, E.L., Pantouvakis, A., and Kafetzopoulos, D.P. (2013). The impact of ISO 900I effectiveness on the performance of service companies. Managing Service Quality: An International Journal 23(2), I49-I64.

Rapp, J.M. (20II). Foreword. In A. Sursock (ed.) Examining Quality Culture Part 2: Processes and Tools-Participation, Ownership and Bureaucracy. Brussels: EUA Publications.

Razavi, S. M., Safari, H., and Shafie, H. (20I2). Relationships among service quality, customer satisfaction and customer perceived value: Evidence from Iran's software industry. Journal of Management and Strategy 3(3), 28-37.

Rodman, K., and Godnov, U. (2010). Social responsibility in ISO gooo Group of Standards for Quality Management Systems. Paper presented at the Social Responsibility, Professional Ethics, and Management, Proceedings of the IIth International Conference, Ankara, Turkey. Available at: http://ideas.repec.org/h/mgt/micpio/87-Io7.html

Rosa, M.J., Sarrico, C.S., and Amaral, A. (20I2). Implementing Quality Management Systems in Higher Education Institutions. In M. Savsar (ed.) Quality Assurance and Management. InTech, I29-I46.

Rosa, M.J., Cardoso, S., Videira, P., and Amaral, A. (2016). Internal quality assurance: A new culture or added bureaucracy? Paper presented at the CHER 29th Annual Conference, University of Cambridge, UK. Available at: https://www.researchgate.net/publication/3I7239505

Roszak, M.T. (2009). Systemic approach to problems of the quality in education. Journal of Achievements in Materials and Manufacturing Engineering 37(2), 75I-758.

Rowlands, J. (2012). Accountability, quality assurance and performativity: The changing role of the academic board. Quality in Higher Education 18(I), 97-IIO.

Salto, D.J. (20I7). Quality assurance through accreditation: When resistance meets over-compliance. Higher Education Quarterly 1-12, https:// doi.org/IO.IIII/hequ.I2I5I

Sanyal, B. C., and Martin, M. (2007). Quality Assurance and the Role of Accreditation: An Overview. In Global University Network for Innovation (ed.) Higher Education in the World 2007. Accreditation for Quality
Assurance: What is at Stake? (2 ${ }^{\text {nd }}$ edition). New York: Palgrave Macmillan, 3-I7.

Schneider, M. (2004). The adequacy of New Jersey public school facilities: Results from a survey of principals. Department of Political Science, State University at Stony Brook, New York: Stony Brook.

Sickinger-Nagorni, R., and Schwanke, J. (2016). The New ISO 9001:2015 - Its opportunities and challenges. Tampere: Tampere University of Applied Sciences. Available at: http://www.theseus.fi/bitstream/ handle/I0024/II3266/Schwanke_Jana_Sickinger-Nagorni_Rajka.pdf ;jessionid=ooA5DC7C5738664AD209IBE9EE32B8F8? sequence=2

Singh C., and Sareen K. (2006). Effectiveness of ISO 9000 standards in Indian educational institutions: A survey. International Journal of Services Technology and Management 7(4), 403-4I5.

Spronken-Smith, R., Bond, C., McLean, A., Frielick, S., Smith, N., Jenkins, M., and Marshall, S. (2013). How to engage with a graduate outcomes' agenda: A guide for tertiary education institutions. Wellington: Ako Aotearoa National Centre for Tertiary Teaching Excellence. Available at: http://akoaotearoa.ac.nz/graduate-outcomes

Srikanthan, G., and Dalrymple J. (2003). Developing alternative perspectives for quality in higher education. International Journal of Educational Management 17(3), I26-136.

Srikanthan, G., and Dalrymple, J. (2004). A synthesis of a quality management model for education in universities. International Journal of Educational Management 18(4), 266-279.

Srinivasan, A., and Kurey, B. (2OI4). Creating a culture of quality. Available at: https://hbr.org/20I4/04/creating-a-culture-of-quality

Standards and Guidelines for Quality Assurance in the European Higher Education Area (ESG). (20I5). Standards and guidelines for quality assurance in the European higher education area (ESG). Brussels, Belgium. Available at: https://enqa.eu/wp-content/uploads/20I5/II/ESG_20I5. pdf

Stensaker, B. (2008). Outcomes of quality assurance: a discussion of knowledge, methodology and validity. Quality in Higher Education 14(I), 3-I3.

Stojanovic, S. (2015). Should universities implement ISO 9001?Available at: https://advisera.com/900Iacademy/blog/2015/04/2I/should-universities-implement-iso-900I/

Tari, J.J., and Dick, G.P.M. (2012). A review of quality management research in higher education institutions. Paper presented at the British Academy of Management (BAM) Cardiff Conference, Cardiff, United Kingdom. Available at: https://kar.kent.ac.uk/37761/1/2012\%20BAM\%20HEI\%20 Contribution\%20638_a.doc

Tavares, O., Sin, C., Videira, P., and Amaral, A. (20I7) Academics' per- 
ceptions of the impact of internal quality assurance on teaching and learning. Assessment \& Evaluation in Higher Education 42(8), I293-I305.

Tetteh, G.A. (2018). Quality in the higher education system: Use of the quality function deployment tool. Quality Approaches in Education 9(I), I7-36.

Thonhauser, T., and Passmore, D. (2006). ISO 9000 in education: A comparison between the United States and England. Research in Comparative and International Education 1(2), I56-I73.

Times Higher Education. (20I5). Is risk-based quality assurance too risky? UK: Times Higher Education. Available at: https://www.timeshighereducation.com/features/is-risk-based-quality-assurance-too-risky.

Tranfield, D., Denyer, D., and Smart, P. (2003). Towards a methodology for developing evidence-informed management knowledge by means of systematic review. British Academy of Management 14, 207-222.

United Nations Educational, Scientific and Cultural Organisation (UNESCO). (2018). Internal quality assurance: Enhancing higher education quality and graduate employability. Available at: http://unesdoc. unesco.org/images/0026/002613/261356e.pdf

Van den Berghe, W. (I997). Application of ISO gooo standards to education and training. Interpretation and guidelines in a European perspective. Thessaloniki: European Centre for the Development of Vocational Training (CEDEFOP).

Van den Berghe, W. (I998). Application of ISO 9000 standards to education and training. Vocational Training: European Journal 15, 20-28.

Vl $\square$ sceanu, L., Grünberg, L., and Pârlea, D. (2007). Quality assurance and accreditation: A glossary of basic terms and definitions. Bucharest: UNESCO-CEPES.

Yuan, L. (20IO). Quality assurance in Chinese higher education. Research in Comparative and International Education 5(I), 58-76.

Zabadi, A. M. (20I3). Implementing total quality management (TQM) on the higher education institutions - A conceptual model. Journal of Finance Q E Economics 1(I), 42-60. 